\title{
A MUSA E HOMERO
}

\author{
Jacyntho Lins Brandão
}

RESUMO: Its is a work about some ideas which appear both in poems of Homero and Hesiodo: the statue of the poet, the poem and its public, considering the features of the greek poem since its origins. Thoese ideas will have essential importance in posterior theories.

PALAVRAS-CHAVE: Homero, musas, Ilíada, Odisséia, Hesíodo, poética.

Verdenius, em artigo dedicado aos princípios da crítica literária grega ${ }^{1}$, aponta algumas idéias mestras que a conformam, expressas nos textos tanto dos poetas arcaicos, quanto dos filósofos, até Platão, a saber: forma, destreza, autoridade, inspiração, contemplação. Decerto, outros parâmetros poderiam ser apontados - como a idéia de que o poema é um patrimônio, no sentido de monumento que se ergue, ou de que é um objeto que será levado, como mercadoria, de porto em porto, as quais encontramos em Píndaro².

Entretanto, o importante é realçar que todos esses pontos de vista constituem a expressão, nos próprios textos, de poéticas que lhes são implícitas, ou seja, através desses enunciados metalinguísticos o poeta confirma ou reflete sobre seu fazer (seu poieîn, sua poética), explicitando o que implicitamente se supõe. Isso significa que, na Grécia, diferentemente de em outras literaturas, sempre foi problemático o estatuto do poeta, do poema e do poético, o que leva à necessidade recorrente de representar o lugar do primeiro, explicitar os processos de composição do segundo e indicar as finalidades das diferentes poéticas.

Recorde-se, apenas para se ter uma perspectiva em contraponto, a impessoalidade, a naturalidade, a confiança com que o narrador do Gênesis judaico conduz seu relato: ele não sente necessidade alguma de apresentar-se (ou representar-se) para seu leitor, não tem de justificar o modo nem a finalidade do que narra, pois existe uma suposição de base, que é tanto sua quanto, sobretudo, de seu destinatário: a de que tudo o que ele diz é nada menos que a palavra de Deus. Num certo sentido, dispensam-se portanto os pressupostos poéticos, da perspectiva de que são supérfluos para a simples comunicação da verdade.

Tendo em vista a especificidade da poesia grega desde suas origens ${ }^{3}$, examinarei algumas idéias registradas tanto nos poemas homéricos, quanto em Hesíodo, relativas a apenas certos conceitos que serão de fundamental importância para as teorias posteriores, a saber: o estatuto do poeta, do poema e de seu público.

\section{PROÊMIOS}

É suficientemente famosa a abertura da Ilíada, que contém um autêntico programa narrativo ${ }^{4}$ :

\footnotetext{
Jacyntho Lins Brandão é professor da Universidade Federal de Minas Gerais.

${ }^{1}$ VERDENIUS, The Principles of Greek Literary Criticism.

${ }^{2}$ Cf. PÍNDARO, que, na décima-primeira Olímpica, põe seus versos melodiosos em pé de igualdade com a "coroa de dourada oliveira" recebida como prêmio por Agesidamo (v. 13-14); na sétima Olímpica, afirma que o poema é como uma "peça de ouro maciço" que um homem opulento oferece ao jovem noivo (v. 5-6); na sexta, diz que o poema é "érgon" que, "como admirável palácio", se constrói (v. 1-5); na segunda Pítica, que a obra é equivalente a uma "mercadoria fenícia", enviada ao rei, pelo poeta, através do cinzento mar (v. 125-126); na sexta Pítica declara-se ainda que, para os vitoriosos, se constrói um "tesouro de hinos", contra o qual nada podem as intempéries (v. 7-14). Na quinta Neméia, o poeta declara não ser um estatuário, que produz figuras estáticas sobre uma base, defendendo para o poema um estatuto de bem que pode ser transportado através dos mares, a fim de difundir a glória do vitorioso (v. 1-6). Nesse sentido, recorde-se a informação do escoliasta Górgon, de que a sétima Olímpica teria sido gravada, em letras de ouro, no templo de Atena em Lindos.

${ }^{3}$ Há outras literaturas em que esses processos metalinguísticos ou metaliterários de representação do poeta, do poema e de seu público são também importantes, como é o caso da literatura sânscrita. Não se trata, entretanto, de princípio de validade geral, mas antes de um traço diferenciador de certas literaturas, dentre as quais a grega.
} 
A cólera canta, deusa, do Pelida Aquiles,

Cólera funesta que inúmeras dores para os aqueus trouxe

E muitas vidas valorosas no Hades precipitou -

Vidas de heróis - e deles pasto fez para os cães

E os pássaros todos, de Zeus cumprindo o desígnio,

Desde quando, primeiro, separaram-se, em conflito,

O Atrida rei dos guerreiros e o divino Aquiles. ${ }^{5}$

O primeiro fato digno de nota é que se trata de um prólogo em segunda pessoa - e não em terceira, como acontece com outras narrativas arcaicas de outras culturas. O narrador do Gênesis, para voltar a referir-me a um exemplo conhecido, começa de chofre sua narrativa:

No princípio criou Deus o céu e a terra. A terra era informe e vazia e as trevas cobriam a face do abismo. E o espírito de Deus pairava sobre as águas. ${ }^{6}$

Nessa postura, o grau de impessoalidade é extremo, no sentido de que toda a elocução se entrega à não pessoa (a que se costuma tratar de terceira, com algum grau de inexatidão ${ }^{7}$ ). Dizendo em outros termos, o narrador do Gênesis intencionalmente não representa as circunstâncias da enunciação: quem fala e para quem fala. Esta opção tem evidentes vantagens, sobretudo para um discurso antes de tudo religioso: ao obscurecerem-se os demais pontos do processo de comunicação, joga-se toda a luz apenas no que se fala, o que dá à narrativa uma espécie de sentido não circunstancial, logo, impessoal e, ainda mais, atemporal, absoluto, verdadeiro em sumo grau. Como conviria, aliás, à própria fala divina, sobre si, para si.

Não é a mesma, evidentemente, a opção do narrador da Ilíada. Nos versos acima citados, temos um esboço da situação de enunciação de todo o poema. De um lado, uma primeira pessoa, não definida, que ordena (ou suplica?) a uma segunda pessoa, bem definida pelo vocativo, a deusa, que cante ${ }^{8}$. A não pessoa é o objeto do canto, isto é: a cólera do Pelida Aquiles. Estabelece-se assim uma relação entre o enunciador e a deusa mais complexa do que um simples processo de inspiração, pelo menos da forma como é normalmente concebido. De um lado, porque é o poeta que toma a iniciativa do canto ${ }^{9}$, através do imperativo dirigido à deusa, decidindo seu objeto (a cólera), qualificando-o (a cólera funesta que inúmeras dores para os aqueus trouxe...), apontando sua motivação (o desígnio de Zeus) e, em especial, estabelecendo o ponto a partir do qual o canto deve desdobrar-se (desde quando, primeiro, separaram-se em conflito o Atrida, rei dos guerreiros, e o divino Aquiles). $\mathrm{O}$ uso da segunda pessoa tem como conseqüência tornar uma enunciação em primeira pessoa esses sete versos iniciais. Eles não se apresentam como um discurso de ninguém, pelo contrário, explicitam, intencionalmente, um lugar para o sujeito da enunciação, ou, em termos concretos, um lugar para o aedo que, diante de um público, profere o canto.

O oitavo verso confirma essa preocupação em representar a situação de enunciação:

Quem pois a eles, dos deuses, pôs a guerrear em conflito? ${ }^{10}$

Ressalte-se a forma interrogativa. Simples pergunta retórica? Pode ser, mas, desde que uma pergunta, leva a que se suponha de quem para quem ${ }^{11}$. Da deusa? Não teria sentido. Só se poderia admitir que se trata de uma pergunta do poeta, que fala de novo, portanto, como ele próprio, em elocução direta. A

${ }^{4}$ KIRK, The Iliad, p. 52, aponta as qualidades tipicamente homéricas deste proêmio: 1) its forceful conciseness; 2) its cumulative expression with runover in 2 and $4 ; 3$ ) its verse-pattern climax (7 is a rising threefolder after mainly twofolders); 4) and its rhetorical transition to the main narrative in $8 f$.

${ }^{5}$ HOMERO, Ilíada, I, 1-7.

${ }^{6}$ Gênesis, I, 1 .

${ }^{7}$ BENVENISTE, Problèmes de linguistique générale, p. 228: «A terceira pessoa não é uma 'pessoa'; é mesmo a forma verbal que tem como função exprimir a não pessoa». De fato, diante das duas pessoas claramente marcadas nos processos de comunicação, a terceira pessoa se distinguiria pela ausência de marca propriamente pessoal. Num certo sentido, a terceira pessoa não é pessoa, é o assunto ou o objeto do discurso. Ver também HARTOG, Le Miroir d' Hérodote.

${ }^{8}$ Observa KIRK, The Iliad, p. 52, que os escoliastas já se interrogavam sobre este detalhe: o poeta antes ordena, que suplica à deusa. Entendo que se trata, de fato, de uma ordem, que marca bem o papel do poeta em sua relação com a Musa.

${ }^{9}$ Uso o termo poeta para indicar tanto a função daquele que compõe o poema, quanto do narrador ou, do enunciador. Na introdução já foi esclarecido como esse sentido só foi atribuído à palavra no século $\mathrm{V}$, sendo portanto anacrônica aplicá-la para falar de Homero. Por outro lado, as preocupações modernas em distinguir o poeta do narrador ou do enunciador são, em certa medida, improcedentes com relação à Grécia antiga, até porque o que sabemos dos poetas gregos em geral é que são os enunciadores dos poemas que deles recebemos. Isso se aplica a Homero: ele é, para nós (e em grande parte também para os gregos do período clássico, helenístico e romano) nada mais que o narrador dos poemas homéricos. Na minha opção pelo termo poeta, tem importância o fato de Platão e Aristóteles utilizarem-no para designar o sujeito da enunciação, bem como as vantagens que há em manter-se, no correr do presente trabalho, alguma coesão terminológica.

${ }^{10}$ HOMERO, Ilíada, I, 8.

${ }^{11}$ KIRK, The Iliad, considera este verso «a rhetorical question designed to highlight the answer, as well as in this case to lead on to the beginning of the story itself». 
quem se dirige? Pois é natural que uma pergunta direta exija quem interroga (a primeira pessoa) e a quem se interroga (a segunda pessoa) ${ }^{12}$. Penso que há duas hipóteses: a primeira, admitir que o poeta se dirige de novo à deusa; a segunda, que se dirigisse a seu público, o que não seria difícil de imaginar, supondo-se uma elocução do poema como as existentes na Odisséia, com o aedo cercado por seus ouvintes. Aliás, admitir que o destinatário da pergunta fosse a deusa levaria a admitir-se também que ela fosse a destinatária do canto. Nesse sentido é que considero mais razoável entender simplesmente que o aedo, ao perguntar, dirige-se preferencialmente a seu ouvinte, efeito que se mantém ainda quando no lugar da segunda pessoa esteja um leitor.

A pessoa do enunciador do canto se definiria então por manter relações com duas segundas pessoas: a primeira, a deusa, a que ordena que cante; a segunda, os ouvintes para os quais canta. Assim delimitados os papéis, a resposta à pergunta introduz-se sem outros rodeios: «De Leto e de Zeus o filho» ${ }^{13}$. Caberia perguntar: quem responde? A deusa ou o ouvinte? A questão provavelmente é improcedente, uma vez que, do mesmo modo que o aedo canta pela deusa, pode responder pelo ouvinte - e, sobretudo, a representação da situação de enunciação do canto já está completa, constituindo este verso, ao mesmo tempo, uma sorte de encaixe e de passagem do proêmio, em essência dramático, para a narrativa propriamente dita.

Examinemos igualmente o proêmio da Odisséia:

O guerreiro diz-me, Musa, ardiloso, que muitíssimo

Vagueou, desde que, de Tróia, a sagrada cidadela pilhou,

E de muitos homens viu as cidades e o espírito conheceu -

E muitas dores ele, no mar, sofreu em seu ânimo,

Lutando por sua vida e pelo retorno dos companheiros -

Mas nem assim os companheiros salvou como queria,

Pois eles, pela própria insensatez, pereceram,

Tolos, que os bois do filho de Hipérion, o Sol,

Comeram: logo este lhes tirou o dia do retorno. ${ }^{14}$

A semelhança com o proêmio da Ilíada é notável, embora aqui pareça haver uma diferença de tom ou um enfoque diverso, como se, de um texto para o outro, independentemente de qualquer ordem de precedência, se procedesse a um ligeiro deslocamento: no primeiro hemistíquio, por exemplo, no lugar dos três simples sintagmas da Ilíada, encontramos agora quatro:

A cólera canta, deusa (Mênin áeide theá)...

O herói diz-me, Musa (Ándra moi énnepe Moûsa)...

Note-se como os termos se correspondem: o imperativo (áeidelénnepe), que introduz a pessoa que fala, o vocativo, que designa a segunda pessoa (theá/Moûsa), e, finalmente o que se ordena que a deusa cante ou diga: a cólera/o herói (mênin/ándra). Assim, em termos de enquadramento da enunciação, aplica-se à Odisséia tudo que foi dito relativamente à Ilíada. Com relação ao objeto da enunciação, também as semelhanças são notáveis: a cólera é determinada pelo adjetivo funesta e logo explanada pelo acréscimo de uma oração adjetiva (ouloménen hè...); o herói recebe, ainda no primeiro verso, a determinação de polýtropon e logo outras através de oração adjetiva (polýtropon hòs...) $)^{15}$.

A correspondência, contudo, não é repetitiva - há algo que se moveu: no primeiro hemistíquio encontramos a explicitação oblíqua de quem se dirige à Musa, um precioso exemplo de primeira pessoa que, gramaticalmente, sai da sombra e vem à luz. O aedo, do mesmo modo que, em vez de dirigir-se genericamente à deusa, a segunda pessoa de sua elocução, se dirige à Musa, também explicita a primeira pessoa através de um moi (a mim ou para mim). No segundo hemistíquio, curiosamente, preferiu não nomear seu herói, Ulisses - contra a nomeação de Aquiles Pelida que preenche todo o segundo hemistíquio do primeiro verso da Ilíada. É verdade que, no primeiro caso, o nome do herói ocorre em genitivo, como determinante da cólera, enquanto aqui o termo ándra não admitiria uma determinação com o nome de Ulisses $^{16}$. Seja como for, o que se constata é que, na Odisséia, se delineiam com mais precisão as figuras do

\footnotetext{
${ }^{12}$ De fato, em geral, os enunciados interrogativos não admitem a não pessoa, como os declarativos ou imperativos podem admitir (por exemplo, em placas como proibido fumar, vire à esquerda). Qualquer interrogação relativiza o enunciado, levando a que se explicite quem o faz, isto é: quem é responsável por ele. Como quando alguém bate numa porta e pergunta: tem alguém aí? A resposta natural, antes de abrir-se a porta, será: quem é?

${ }^{13}$ HOMERO, Ilíada, I, 9.

${ }^{14}$ HOMERO, Odisséia, I, 1-9.

${ }^{15}$ Outros detalhes: ; a perda da vida ( ); os atos motivadores do desfecho funesto (a dissenção entre Agamêmnon e Aquiles; a insensatez dos companheiros de Ulisses); os deuses responsáveis (Zeus e Posêidon).

${ }^{16} \mathrm{O}$ nome de Ulisses aparece apenas no verso 21.
} 
aedo e da Musa, esmaecendo-se o objeto do canto. Isoladamente, cada um dos poemas faz suas escolhas e tem seus efeitos; um em face do outro, essas escolhas e esses efeitos manifestam o que têm de peculiar, levando a que se percebam com mais clareza os mecanismos que situam a enunciação e os programas narrativos.

Outro ponto de contato entre os dois proêmios é o verso que, como encaixe e passagem, fecha a introdução da Odisséia, de caráter também dramático, já que se dá entre uma primeira e uma segunda pessoa:

Disso, desde algum ponto, deusa, filha de Zeus, fala também a nós. ${ }^{17}$

Este enunciado equivaleria à pergunta que encontramos na Ilíada. Lá, o aedo dirigia-a à deusa ou a seu público - ou a ambos. Aqui, trata-se de um discurso que também tem uma segunda pessoa, a deusa, filha de Zeus, numa sorte de segunda invocação, sob a forma de uma ordem mais precisa, expressa pelo imperativo. Essa segunda invocação inclui ainda um dado que, na Ilíada, se encontrava nos dois versos anteriores ao encaixe-passagem, como parte do programa narrativo (desde quando, primeiro, se separaram como rivais o Atrida... e Aquiles), isto é, versos em que se estabelece para a Musa (e para o público) o ponto de partida da narrativa; na Odisséia, deixa-se a escolha aberta à própria Musa: fala dessas coisas a partir de qualquer ponto $^{18}$. Ainda que alimentemos todas as dúvidas antigas e modernas sobre a primitiva forma da Odisséia, não posso deixar de observar que, em vista da Ilíada, ela tem uma estrutura mais complexa: embora o núcleo seja o que se ordena à deusa que diga (o nóstos de Ulisses e de seus companheiros ${ }^{19}$ ), esse começar de qualquer ponto, na forma atual do poema, pode dizer respeito justamente aos múltiplos aspectos do programa narrativo: um ponto de partida será a Telemaquia; outro ponto de partida o nóstos de Ulisses, da Ilha de Calipso até Ítaca; outro ponto de partida seria o nóstos de Ulisses de Tróia até a Ilha de Calipso, narrado pelo próprio Ulisses; outro ponto de partida seria a reconquista da casa, após sua chegada em Ítaca. Ou seja: estaríamos diante de um programa narrativo complexo, que explicaria a sensação do leitor (antigo e moderno) de estar diante de vários poemas que, entretanto, formam um só, através de uma engenhosa arquitetura $^{20}$.

Finalmente, a segunda invocação amplia o destinatário do canto, através do uso de hemîn (a nós ou para nós). Quem seria este nós: eu e tu (isto é: o aedo e a Musa) ou eu e ele(s) (o aedo e seu público)? Não passaria de um simples equivalente de moi, um plural majestático ou de modéstia? Entre as várias hipóteses, todas linguisticamente defensáveis, tenderia a admitir menos a última que as duas primeiras, pelo motivo de que estaríamos diante de equação equivalente à que encontramos no verso 8 da Ilíada: há a deusa, a que o poeta se dirige; mas há também o ouvinte a que ele também, pragmaticamente, se dirige. Assim, creio que hemîn corresponda preferentemente a eu e ele(s), da perspectiva do enunciado que tem a deusa como segunda pessoa, um eu e ele(s) que poderia ser entendido também como um eu e vós (meus ouvintes), do ponto de vista da enunciação do canto.

Ora, cumpriria perguntar que sentido tem a tão propalada objetividade homérica, quando se define, com tanta precisão, o lugar do enunciador, da enunciação e do público, em trechos de total responsabilidade do primeiro. Não posso concordar que estejamos diante de um discurso impessoal, que é todo da Musa, a qual apaga a figura do poeta e o conduz. Pelo contrário, parece-me que este quer marcar justamente o que lhe cabe, explicitando seu lugar, o da Musa e o de seu público, bem como ditando à deusa seu programa narrativo. É o poeta que, naquilo que a Musa oferece, procede às escolhas: o que cantar, de qual perspectiva, partindo de onde, por que motivos. Se falta a «assinatura» ao poema, nem por isso temos de concluir que se perca a enunciação na impessoalidade, que apenas se use, sem discernimento do sujeito da enunciação, um conjunto de «informações estocadas para reutilização», logo, impessoais, como quer, dentre outros, Havelock $^{21}$. No mínimo, a relação do poeta com a Musa é dialética e, mais que inspiração, no sentido de ser conduzido por algo que se encontra fora de si, estamos diante de um processo de cooperação, em que nenhum dos sujeitos abre mão de seu papel. Depois de toda a ênfase se que pôs no papel da Musa nos

\footnotetext{
${ }^{17}$ HOMERO, Odisséia, I, 10.

${ }_{18}$ Assim prefiro entender o termo , cujo sufixo tem esse valor claramente de procedência, e não um valor modal, que significaria de qualquer modo. Cf. também STANFORD, The Odyssey, s.v.

${ }^{19}$ Isto é: a grosso modo, o objeto do relato de Ulisses aos feácios (cantos IX-XII).

${ }^{20}$ Sobre essa arquitetura, ver DELEBECQUE, La Construction de l'Odyssée.

${ }^{21}$ HAVELOCK, A invenção da escrita na Grécia e suas consequências culturais.
} 
últimos decênios ${ }^{22}$, creio que cumpre redescobrir o lugar do poeta que, mesmo que ainda não se chamasse por este nome, tem já consciência de seu papel, que poderíamos definir como uma função poética.

\section{AS MUSAS DE HOMERO}

Busquemos entender mais claramente como se dá essa cooperação do poeta com a Musa, retirando mais do que declaram os próprios poemas homéricos. Na chamada segunda invocação, que antecede o catálogo das naus, encontramos o seguinte:

Dizei agora a mim, Musas que a olímpica morada tendes,

Pois vós sois deusas, presentes estais e sabeis tudo -

Enquanto nós a fama apenas ouvimos, nada sabemos -

Quem os chefes dos dânaos e seus condutores eram. ${ }^{23}$

De início, a invocação, como nos versos de abertura da Odisséia, marca a segunda pessoa (vós, as Musas que tendes a olímpica morada), tão bem quanto a primeira, em forma oblíqua (dizei-me agora). O surpreendente, contudo, em termos de avanço com relação ao até aqui analisado, são os dois versos que se intercalam entre o imperativo do poeta às Musas e o objeto que se ordena que elas agora digam - dois versos cujo objetivo é esclarecer a competência de cada um. O paralelismo é evidente: hymeîs gàr (pois vós)/hemeîs dè (enquanto nós).

A quem se referem vós e nós? Vós são as Musas, que são deusas; nós, o aedo e quaisquer outros eles (como, por exemplo, outros aedos ou todos os homens, por oposição às deusas), ou o aedo e o público a que, num outro plano, se dirige (isto é: um nós que corresponderia a eu e ele(s), no nível do enunciado, mas a um eu e tu/vós, meu(s) recebedor(es), no nível da enunciação). Não julgo que essas hipóteses sejam excludentes. Esse nós apenas não poderia ser, neste ponto, eu e vós, as Musas, já que se processou a uma distinção fundamental: vós sois deusas; logo, nós supõe não deuses, mortais, humanos. Assim, poderíamos voltar ao exemplo anterior, admitindo que também lá hemîn se refira ao mesmo que aqui, eliminando-se a possibilidade de incluir as Musas.

Que distinção se faz, além dessa, entre vós, as deusas e nós? O paralelismo dos dois versos é notável e o jogo de oposições se faz, praticamente, palavra por palavra. Visualizemo-lo graficamente, com a ajuda do esquema rítmico:

$$
\begin{aligned}
& \text { hymeîs } \mid \text { gàr theaî } \mid \text { este }|| \text { pá } \mid \text { resté te } \mid \text { iste te } \mid \text { pánta } \\
& \text { hemeîs } \mid \text { dè kléos } \mid \text { oion }|| \text { a } \mid \text { koúomen } \mid \text { oudé ti } \mid \text { ídmen. }
\end{aligned}
$$

Da mesma forma que hymeîs opõe-se a hemeîs, o páreste (estais presentes) relativo às Musas opõe-se a nosso akoúomen (ouvimos), o que leva a que, enquanto elas sabem tudo por tudo ter visto, nós nada sabemos ou temos visto, considerando-se que os verbos que aqui expressam saber (íste e ídmen), nada mais são que resultativos de ver (logo, saber algo, na concepção grega, equivale especificamente a ter algo visto ${ }^{24}$ ). Ora, o que está em jogo é a diferença entre o que se vê e o que se ouve: as deusas presenciam e têm tudo visto; os homens, nós, temos nada visto, porque ouvimos. Ouvimos o quê? Só um kléos (um rumor) ${ }^{25}$. Isto é: nós ouvimos só o kléos, dependemos do kléos, somos só kléos porque temos nada visto. Os maiores dentre nós - os chefes e condutores dos dânaos, os heróis objeto do canto - nada são sem o kléos. Isso implica que ver (ou melhor: ter a coisa vista, que é uma espécie de ver que não se perde na pluralidade das visões efêmeras, logo é saber ${ }^{26}$ ) é apanágio das deusas, tanto quanto o não ver (ou não ter nenhuma coisa vista, logo sabida) o é de nós, o poeta, seu público, seus heróis. No lugar dessa visão adquirida pela presença

\footnotetext{
${ }^{22}$ Dentre outros, pelos integrantes da Escola de Paris: VERNANT, Mito e pensamento entre os gregos; VERNANT, Mito e sociedade na Grécia antiga; DETIENNE, A invenção da mitologia; DETIENNE, Os mestres de verdade na Grécia arcaica; HARTOG, Le Miroir d'Hérodote (introdução à edição de 1992: Le Vieil Hérodote). Eu próprio explorei esses aspectos em breve nota intitulada: Sobre a gênese dos poemas homéricos.

${ }^{23}$ HOMERO, Ilíada, II, 484-487. Ver comentários em KIRK, The Iliad, p. 166-168.

${ }^{24}$ Esse detalhe etimológico representa mais que simples curiosidade: marca uma postura tipicamente grega relativa ao estatuto do conhecimento, como bem realçou ARENDT, A vida do espírito. Comentei o tema em BRANDÃO, Nós e os gregos.

${ }^{25}$ Isto é: um $\kappa \lambda \varepsilon \varpi \circ \forall \forall$ ot|ov que, no verso referente a nós, ocupa o espaço que, no verso referente às Musas, se preenche com a declaração de sua divindade: $\theta \varepsilon \alpha 1 \Phi \varepsilon \varphi \sigma \tau \varepsilon$.

${ }^{26}$ Cf. o valor de ot $\therefore \delta \alpha$ (saber), na origem um resultativo de ver $(\varepsilon 1 . \delta \delta$ ) $)$.
} 
que dura (páreste), perene, nós experimentamos uma duração de ouvir (akoúomen) que foge com o presente ou dura só o que dura o presente.

Mas, afinal, de onde provém este kléos que ouvimos? É o que se esclarece nos versos seguintes:

A multidão eu próprio não diria nem nomearia

Nem se dez línguas e dez bocas eu tivesse,

Voz infrangível e brônzeo peito em mim houvesse,

Se as Olimpíades Musas, de Zeus portador da égide

Filhas, não lembrassem quantos a Tróia foram. ${ }^{27}$

Agora o poeta não só usa a primeira pessoa do singular - aquela sobre a qual não pode pairar dúvida de a quem se refere e, em certo sentido, fundamenta de qualquer processo enunciativo (direi e nomearei - mythésomai e onoméno) - como a reitera com um enfático egó: eu próprio. De um lado, portanto, encontra-se este eu; de outro, agora, uma terceira pessoa (lembrassem - mnesaíato), que cobre a esfera anterior do vós, referindo-se às Musas Olimpíades, filhas de Zeus que tem a égide. O poeta marca então sua posição através de duas negativas: não diria nem nomearia. Mais ainda: a multidão eu não diria nem nomearia, nem se dez línguas e dez bocas tivesse (novo reforço da negação - oud' - a par de reforço da primeira pessoa - moi - literalmente: nem se para mim houvesse dez línguas e dez bocas). A isso se ajunta ainda novo reforço da primeira pessoa, na sequiência que continua negativa: voz infrangível e brônzeo peito em mim houvesse. Esse é o estatuto limitado do poeta, ao qual faltam recursos ilimitados na esfera dos órgãos ligados à proferição do canto: a língua, a boca e o peito (o coração, o ânimo).

Por outro lado estão as Musas, cuja cooperação com o poeta é indispensável. O que se espera delas? Que rememorem (mnesaíato) quantos sob as muralhas de Tróia estiveram. É assim que se processa a cooperação: às Musas cabe rememorar, ao poeta cantar o que elas rememoram. Tanto é assim que o verso 484 («dizei agora a mim, Musas, que a olímpica morada tendes») repete-se em outros pontos em que o poeta sente necessidade de uma extrema exatidão, a saber: no canto XI, antes de referir a lista dos guerreiros que se bateram contra Agamêmnon ${ }^{28}$, bem como no canto XIV, antes do catálogo dos guerreiros caídos após Posêidon ter mudado o rumo da batalha ${ }^{29}$. Essa capacidade de exatidão não se esgota, entretanto, numa mnemotécnica de catálogos, como se comprova na quarta ocorrência do citado verso, no início do canto XVI, imediatamente antes da volta de Pátroclo à batalha, em que se pede às Musas que digam

Como pois primeiro o fogo caiu nas naves dos aqueus ${ }^{30}$.

Na referência às Musas em terceira pessoa, no canto II, há ainda um dado extremamente importante relativo à questão das relações entre o poeta e as deusas. Em primeiro lugar, ao dizer

A multidão eu próprio não diria nem nomearia...

Se as olimpíades Musas, de Zeus portador da égide

Filhas, não lembrassem quantos a Tróia foram,

\footnotetext{
${ }^{27}$ HOMERO, Ilíada, II, 488-492.

${ }^{28}$ HOMERO, Ilíada, XI, 218-220:

Dizei agora a mim, Musas, que a olímpica morada tendes,

Quem pois primeiro contra Agamêmnon foi -

Dentre os próprios troianos ou ilustres aliados.

Segue-se o catálogo dos guerreiros.

${ }^{29}$ HOMERO, Ilíada, XIV, 508-510:

Dizei agora a mim, Musas que a olímpica morada tendes,

Quem pois primeiro, dos aqueus, despojos sangrentos

Ergueu, depois que para eles fez pender a luta o ilustre Sacudidor da Terra.

Segue o catálogo dos guerreiros.

${ }^{30}$ HOMERO, Ilíada, XV, 112-113. O canto XV termina mostrando como Ájax defende as naus do perigo do fogo que se esforçam em atear-lhes os troianos. O canto XVI abre-se com o colóquio entre Aquiles e Pátroclo, quando, diante das lágrimas deste, o primeiro concorda que acuda os aqueus em iminente perigo. Os versos 101-102, como encaixe-passagem, retornam a cena para a batalha: Assim eles, por um lado, isso com o outro falavam

E, por outro lado, Ájax não mais se mantinha, pois é dominado pelos dardos (beléesin).

Antes de prosseguir, o poeta invoca de novo as Musas:

Dizei agora a mim, Musas que a olímpica morada tendes,

Como pois primeiro o fogo caiu nas naus dos aqueus...

Os dez versos seguintes narram, com detalhe, como Heitor rompe a lança de Ájax, este recua e os troianos lançam o fogo nas naus. Tão importante e indispensável é este entrecho para o desdobramento da narrativa, que é logo que começa o incêndio que Aquiles ordena a Pátroclo que se arme, para impedir que os troianos tomassem as naus, tornando impossível a fuga dos guerreiros. Começa assim a aristeía de Pátroclo, que culminará na sua morte, a qual, por sua vez, provocará o retorno de Aquiles à luta. Como observa JANKO, The Iliad, p. 331, embora as Musas, nos outros pontos citados, sejam invocadas para dizer quem primeiro fez algo, aqui o são para dizer como primeiramente algo se passou.
} 
o poeta declara algo, em primeira pessoa, dirigindo-se pragmaticamente a seus ouvintes, já que não se trata mais de uma ordem às Musas que cantem, mas de uma sorte de avaliação de sua própria capacidade enquanto poeta. Quando, portanto, no verso 493 - que tem a função de encaixe-passagem - ele conclui o raciocínio anterior, afirmando

Os chefes assim das naus direi e as naus todas ${ }^{31}$,

explicita, para seu ouvinte, a opção de não referir-se à multidão (plethýs) que as Musas conhecem, mas resumi-la referindo-se aos chefes e às naus, compreendendo-se nas naus o registro do número de seus tripulantes. Este eréo (direi), em primeira pessoa, entendido como opção alternativa para a referência à quem era cada um que compunha a multidão, implica uma escolha do poeta - que, digamos, não segue a Musa automaticamente, mas elege na competência da deusa o que a ele compete ou cabe dizer ${ }^{32}$. Poderíamos entender, assim, todo o trecho anterior como uma sorte de explicação de por que não se referirá ele à multidão, mas apenas aos chefes e às naus. Por outro lado, o mesmo trecho garante que as Musas sabem bem quem é a multidão, embora dizer isso não seja da competência do poeta, que disso se desobriga: nem se dez línguas... ${ }^{33}$ Como no prólogo da Ilíada, é o poeta que define os limites ao saber tudo que é próprio das Musas, dando-lhe uma dimensão humana, que se efetiva no canto. Não só ele é sujeito da enunciação, mas é seu principal sujeito, enquanto sua medida e seu limite.

\section{DEMÓDOCO}

A Odisséia é rica na representação do estatuto e do lugar do aedo e de seu público, quando põe em cena Fêmio e Demódoco. Examinemos o que se diz a propósito deste último ${ }^{34}$.

Demódoco é qualificado inicialmente, por Alcínoo, como theîon aoidón (divino aedo); ainda, segundo a mesma personagem, a ele, sem dúvida, um deus deu, com o canto, alegrar, quando o ânimo o incita a cantar. ${ }^{35}$

Em seguida, é o próprio narrador que denomia Demódoco como theîon aoidón ${ }^{36}$; depois, trata-o de eríoron aoidón (bravo aedo), acrescentando:

a ele a Musa muito amou e deu tanto um bem, quanto um mal:

dos olhos privou-o e deu-lhe agradável canto. ${ }^{37}$

Demódoco é honrado com um lugar no centro dos convivas ${ }^{38}$, o que comprova o reconhecimento social de seu estatuto elevado, pelas relações que mantém com a Musa. O tema da cegueira, como privação compensada pelo canto (ou como conseqüência dele), é suficientemente produtivo levando-se em conta a tradição referente ao próprio Homero, a qual o representa cego, o que significaria que, do ponto de vista da recepção da obra, se atribui ao poeta um traço de sua personagem, permitindo que se possam atribuir

\footnotetext{
${ }^{31}$ HOMERO, Ilíada, II, 493.

${ }^{32}$ A partícula $\alpha v \therefore$ daria margem a duas leituras: ou no sentido da sucessão: os chefes das naus em seguida direi...; ou no sentido de oposição: os chefes das naus, pelo contrário, direi... Concordo com a posição de KIRK, The Iliad, p. 168, de que o adequado seja o primeiro sentido, já que ele não dirá quem é a multidão, mas apenas quantos ( ) a compunham - ou seja, o que pede à Musa que rememore.

${ }^{33}$ De fato, o catálogo propriamente dito fecha-se com variante do verso 487,

Estes pois os chefes dos dânaos e condutores eram (II, 760),

o que garante que é isso que interessa ao poeta. Em 761 ele volta a invocar a Musa, para agora fazer um pequeno catálogo dos melhores guerreiros e seus cavalos:

A quem pois deles em muito o melhor era, tu própria me dize, Musa,

Deles e dos cavalos, os quais com os Atridas seguiam. (II, 761-762)

Ver comentários em KIRK, The Iliad, p. 240. Sobre o que sabem as Musas e o que escolhe dizer o poeta, comenta o mesmo KIRK, The Iliad, p. 167: «with the Muses' help he can manage to deal with the leaders, but the troops lie beyond his powers - not beyond the Muses', presumably, but their instrument is too fragile, the sheer number are too large». Acredito que é importante, ao optar-se por dizer apenas quanto eram os guerreiros, garantir aos ouvintes que a memória de quem eram, consequentemente, não se perde, pois dela cuidam as Musas, filhas de Zeus.

${ }^{34}$ Além desses dois exemplos, há ainda, na Ilíada, o de Aquiles que canta. Ver

${ }^{35}$ HOMERO, Odisséia, VIII, 44-45.

${ }^{36}$ HOMERO, Odisséia, VIII, 47.

${ }^{37}$ HOMERO, Odisséia, VIII, 62-64.

${ }^{38}$ HOMERO, Odisséia, VIII, 65-66.
} 
também os demais: ser divino, amado pelas Musas e alegrar com cantos agradáveis, quando o incita o ânimo.

Terminada a refeição,

A Musa pois ao aedo impeliu a cantar a fama dos guerreiros,

Do entrecho cuja fama então ao amplo céu chegava,

A disputa de Ulisses e do Pelida Aquiles

Quando se afrontaram no banquete festivo dos deuses... 39

Observe-se como se encontram aqui, narrados, os movimentos dramatizados nos prólogos da Ilíada e da Odisséia: a Musa impele o aedo a cantar a fama dos heróis, a partir de um entrecho, cuja fama chega ao vasto céu, a saber, a disputa de Ulisses e Aquiles, quando... ${ }^{40} \mathrm{O}$ que então ressalta é que não cabe no modelo dos prólogos o registro da fama da própria oíme (narrativa, poema): o poeta, em primeira pessoa, não faz referência a isso com relação a sua própria composição, embora como narrador possa fazê-lo com relação a um entrecho famoso - seja entendido como um assunto muito cantado pelos aedos, seja como um poema mais ou menos no sentido de uma composição .

O canto seguinte de Demódoco, acompanhado de dança ${ }^{41}$, embora introduzido em discurso indireto, permite perceber o que seria seu proêmio, em que se referiria o objeto do canto, seguido de oração subordinada destinada a marcar a partir de onde se começa:

Então o citaredo lançou-se belamente a cantar

$\mathrm{O}$ amor de Ares e da coroada Afrodite,

Como primeiro se uniram na casa de Hefesto,

Às ocultas... ${ }^{42}$

Aos poucos, o relato deixa de ligar-se ao aeídein da abertura, para passar a ser representação direta do próprio canto de Demódoco, o que parece que se dá inteiramente a partir do verso 272, já que nos anteriores seria preciso admitir a mudança de registro enunciativo cortando algum dos versos. Quando mais à frente se introduzem discursos diretos das personagens (a partir do verso 292), não resta dúvida de que se abriu um novo quadro narrativo (uma nova janela ${ }^{43}$ ), em que se representa um narrador dentro da narrativa maior.

A terceira apresentação de Demódoco é provocada por Ulisses. Este afirma reverenciá-lo acima de todos os mortais ${ }^{44}$, pois

Ou a ti próprio a Musa ensinou, filha de Zeus, ou a ti ensinou Apolo ${ }^{45}$.

Mais ainda, continua ele:

...tão conforme a ordem, dos aqueus, o infortúnio cantas,

Como se tu próprio o tivesses presenciado, ou de um outro ouvido ${ }^{46}$.

Após esses encômios, é o próprio Ulisses que dá ao aedo o tema e o programa narrativo, na forma usual nos proêmios:

Mas eia! prossegue e a história do cavalo canta,

O qual então, na acrópole, com dolo, conduziu o divino Odisseu,

De heróis repleto, os quais Ílion pilharam. ${ }^{47}$

Trata-se de uma sorte de desafio: caso Demódoco se saia bem ${ }^{48}$, então dirá Ulisses a todos os homens que um deus bem disposto lhe inspira o canto ${ }^{49}$. Demódoco é logo movido por um deus e começa a cantar:

Assim disse. E ele, excitado por um deus, começou e tecia o canto

\footnotetext{
${ }^{39}$ HOMERO, Odisséia, VIII, 73-76.

${ }^{40}$ Não resisto ao exercício lúdico de imaginar como seria, em discurso direto, esse início do poema de Demódoco, reconstituindo-o, ainda que imperfeitamente, a partir de imitação da introdução da Ilíada:

$\mathrm{N} \varepsilon \imath \kappa \kappa \circ \forall \alpha[\varepsilon \imath \delta \varepsilon \theta \varepsilon \alpha ; \Pi \eta \lambda \eta \iota \alpha \delta \varepsilon \omega \omega ! \mathrm{A} \chi \imath \lambda \eta \ni о \forall$

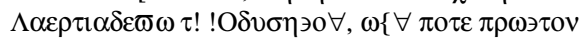

$\alpha[\mu \phi \omega \delta \eta \rho \iota \varpi \sigma \alpha \nu \tau 0 \theta \varepsilon \omega \ni \vee \varepsilon \varphi \nu \delta \alpha \imath \tau \imath ; \theta \alpha \lambda \varepsilon \imath \varpi \eta \ldots$

A dispura canta, deusa, do Pelida Aquiles

E do Laertida Odisseu, quando então primeiro

Ambos se afrontaram no banquete festivo dos deuses...

${ }^{41}$ Há restrições com relação à autenticidade destre trecho, que entretanto não são suficientes para torná-lo indigno de consideração.

${ }^{42}$ HOMERO, Odisséia, VIII, 266-269.

${ }_{43}^{43}$ Esta bela imagem, inspirada pelos programas de computadores, foi-me sugerida por Pedro Ypiranga Júnior.

${ }^{44}$ HOMERO, Odisséia, VIII, 487.

${ }^{45}$ HOMERO, Odisséia, VIII, 488.

${ }^{46}$ HOMERO, Odisséia, VIII, 489-490. Cf. a tradução de Bérard: «l'as-tu vu de tes yeux ou par les yeux d'un autre?»

${ }^{47}$ HOMERO, Odisséia, VIII, 492, 494, 495.

${ }^{48}$ HOMERO, Odisséia, VIII, 496.

${ }^{49}$ HOMERO, Odisséia, VIII, 498.
} 
Tomando do ponto como eles, nas naus de boas pranchas,

Avançando, partiam a navegar, fogo nas tendas tendo posto,

Os argivos.... ${ }^{50}$

O discurso indireto é garantido por esse hos inicial (énthen helòn hos: tomando [a história] do ponto como...), reiterado cinco versos depois ${ }^{51}$. Nove versos abaixo volta-se a marcar o discurso indireto, incluindo a repetição do verbo dicendi (éeiden, cantava), o que acontece, mais uma vez, dois versos depois disso e, de novo, no penúltimo verso relativo ao canto de Demódoco ${ }^{52}$. Essa reiteração de marcas indiretas do discurso é aqui necessária, já que se trata de um trecho relativamente longo (20 versos), contra os apenas seis referentes ao nê̂kos de Aquiles e Ulisses.

As lágrimas de Ulisses são a prova de que Demódoco cumpriu o desafio ${ }^{53}$. Em todos os demais entrechos não se deixa de observar os efeitos do canto: ao ouvirem o episódio do neîkos, os feácios se alegram (térpont'epéesin ${ }^{54}$ ) e Ulisses chora ${ }^{55}$; todos, incluindo Ulisses, alegram-se com a histórias de Ares e Afrodite ${ }^{56}$; finalmente, Ulisses volta a chorar ao ouvir o canto sobre o cavalo de madeira e supõe-se, pela fala de Alcínoo, que os feácios de novo se encantam ${ }^{57}$.

Vê-se como se apresenta a situação de enunciação: o aedo é respeitado e sabe-se que mantém relação com as Musas e Apolo; o aedo, impulsionado pela Musa, pode escolher o tema do canto (como no caso do neîkos); sem referência às deusas, pode também fazê-lo (o que se constata com respeito ao entrecho de Ares e Afrodite) ou acatar sugestões dos ouvintes (como se vê com relação ao cavalo de madeira). $\mathrm{O}$ aedo interage com seu público e os efeitos do canto são visíveis, expressos sobretudo como térpesthai. O canto é apreciado e, em torno dele, há também um kléos, como em torno dos argumentos que propaga. Cada canto tem um programa, que se define basicamente como um ponto de partida - como se explicita na abertura dos próprios poemas homéricos. Finalmente, o público não é passivo, sofrendo os efeitos do canto, mas também determina seu início e fim, podendo mesmo, como faz Ulisses, propor programas narrativos.

Tudo isso parece ter duas consequências principais: a primeira, desautorizar a redução da poética homérica à teoria da inspiração; a segunda, levar a admitir-se que o que se expõe é um processo complexo, envolvendo a colaboração entre a Musa, o poeta e os ouvintes, o qual intencionalmente pretende apresentar-se como complexo. Sem prejuízo de outras interpretações, do ponto de vista formal acredito ser necessário admitir que o papel da Musa seja justamente explicitar a função poética em seus vários níveis, isto é: fazer ver como se constrói o poema, através da dramatização das relações entre quem faz e quem ouve.

\footnotetext{
${ }^{50}$ HOMERO, Odisséia, VIII, 499-502.

${ }^{51}$ HOMERO, Odisséia, VIII, 505.

${ }^{52}$ HOMERO, Odisséia, VIII, 514, 516, 519-520.

${ }^{53}$ HOMERO, Odisséia, VIII, 521 ss.

${ }^{54}$ HOMERO, Odisséia, VIII, 91.

55 HOMERO, Odisséia, VIII, 83-90.

${ }^{56}$ HOMERO, Odisséia, VIII, 367-369.

${ }^{57}$ HOMERO, Odisséia, VIII, 536 ss.
} 